\title{
Potency Analysis of the Batik MSMES Industrial in Surabaya Using Geographic Information System
}

\author{
Wijaya Justian dan Muhammad Taufik
}

\begin{abstract}
Behind the slowing global economic growth, MSME sector plays a very important role in maintaining the stability of national economy. In 2016 the contribution of the MSME sector reaches $60.34 \%$ for the national gross domestic product (GDP). Batik itself is a cultural heritage of the archipelago that has been recognized by the world through UNESCO as a masterpiece of humanitarian heritage for oral and nonbendawi culture (Masterpiece of The Oral and Intangible Heritage of Humanity). So in order to support and develop the sector of batik MSMEs in Surabaya required a system to monitor and analyze the potential of MSMEs in Surabaya batik is the construction of geographic information systems. The purpose of this research is to make a potential map of MSMEs of Surabaya city batik and GIS potency of batik MSME Surabaya city, which obtained by using scoring method based on distance parameter to transportation access, price range and completeness of batik product MSMEs in Surabaya. As reference and recommendation for related parties in developing potency of batik MSMEs in Surabaya. The results of the potential analysis of batik MSMEs in Surabaya are classified into 3 priority classification of high, medium, and low priority. Results of regional analysis that has MSMEs batik with high priority that is 13 MSMEs spread in South Surabaya amounted to 5 MSMEs, Central Surabaya amounted to 6 MSMEs, and North Surabaya amounted to 2 MSMEs. Then the medium priority of 24 MSMEs spread in South Surabaya amounted to 5 MSMEs, Central Surabaya amounted to 17 MSMEs, and North Surabaya amounted to 2 MSMEs. While the low priority of 4 MSMEs spread across Central Surabaya amounted to 1 MSMEs and North Surabaya amounted to 3 MSMES.
\end{abstract}

Keywords-Potential of MSMEs Batik, Geographic Information System, Scoring Analysis.

\section{INTRODUCTION}

Recent global economic growth is in a slowing trend. In 2016 global economic growth only reached 3.2\%. This figure is far when compared to global economic growth in 2011 which reached 5.4\% [1]. The slowing down of the global economy has become one of the impacts of the economic downturn in Indonesia. Public purchasing power has decreased almost in all business sectors [2].

UMKM is an abbreviation of micro, small and medium enterprises. UMKM is regulated based on Law Number 20 of 2008 on micro, small and medium enterprises. Where

Wijaya Justian dan Muhammad Taufik are with Department of Geomatics Engineering, Institut Teknologi Sepuluh Nopember, Surabaya, 60111, Indonesia. E-mail: taufik_m@geodesy.its.ac.id.
UMKM is a stand-alone productive economic enterprise, carried out by an individual or business entity that is not a subsidiary or a branch of a company owned, controlled, or becomes part directly or indirectly with a Small Business or a large business with a net worth or the results of annual sales as stipulated in the Act [3]. Behind the current economic slowdown, the MSME sector is one of the excellent contributors to the stability of the national economy. The ability of UMKM has proven able to sustain the economy during the economic crisis of 1997-1998. In 2016 the contribution of the MSME sector reaches $60.34 \%$ for the national gross domestic product (GDP) national [4][5].

Surabaya is one of the metropolitan cities as well as the capital of East Java province. Therefore, Surabaya became the center of economic activity in East Java and its surroundings, so that Surabaya has a big role in creating jobs for people of Surabaya and other areas around Surabaya [6]. Batik is a cultural heritage of the archipelago (Indonesia) which has a high value and fusion of art, loaded with philosophical meanings and meaningful symbols that show the way of thinking of the creator community. Batik is a craft that has become part of Indonesian culture (especially Java) since the first [7]. Batik skills are used as a livelihood and exclusive work for Javanese women until the discovery of batik cap and printing that allows the entry of men in this batik work. Batik development in Indonesia peaked on October 2, 2009, namely UNESCO (United Nations Educational, Scientific and Cultural Organization) set Batik Indonesia as a whole technique, technology, development of motifs and cultures associated with the batik as a masterpiece of humanitarian heritage for oral culture and non bendawi (Masterpiece of The Oral and Intangible Heritage of Humanity) is the international recognition that Indonesian batik is part of the wealth of human civilization.

Geographic Information System can be utilized to support UMKM activity in batik field in Surabaya city. Spatial analysis of SMEs generated from GIS can make it easier for the parties involved in making a decision. Information generated GIS can be made in detail so that the need for information will be very fulfilled.

\section{RESEARCH METHOD}

\section{A. Research Sites}

The research location of this final project is in Surabaya City, East Java Province. The city of Surabaya has an area of about $350.5 \mathrm{~km} 2$ and is geographically located between $7^{\circ}$ 09 's to $7^{\circ} 21^{\prime} \mathrm{S}$ and $112^{\circ} 36$ 's to $112^{\circ} 54^{\prime} \mathrm{E}$. 
The $3^{\text {rd }}$ Geomatics International Conference 2018

July $12^{\text {th }} 2018$, Institut Teknologi Sepuluh Nopember, Surabaya, Indonesia

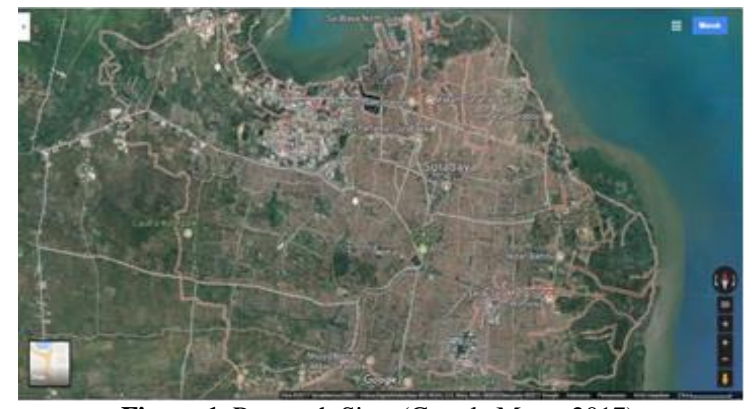

Figure 1. Research Sites (Google Maps, 2017).

\section{B. Data and Equipment}

Data needed in this research are:

1. Spatial data in the form of digital map of Surabaya city in format (. Shp) and coordinate result from GPS

2. Non spatial data used are primary data (questionnaire survey) and secondary data about batik SMEs in Surabaya city from Surabaya Small and Medium Business Cooperative Office

Equipment used in this research is as follows:

a) Operating system windows 7, used for preparing reports and preparation database SMEs Surabaya batik ArcGIS 10.0,

b) ArcGIS 10.0, used to perform the process of making database and analysis of batik SMEs Surabaya

c) CarryMap, an open source application used to design and display simple to complex maps that are porTable so easy to use by common people.

\section{Research Method}

The processing stage is described with the following explanation:

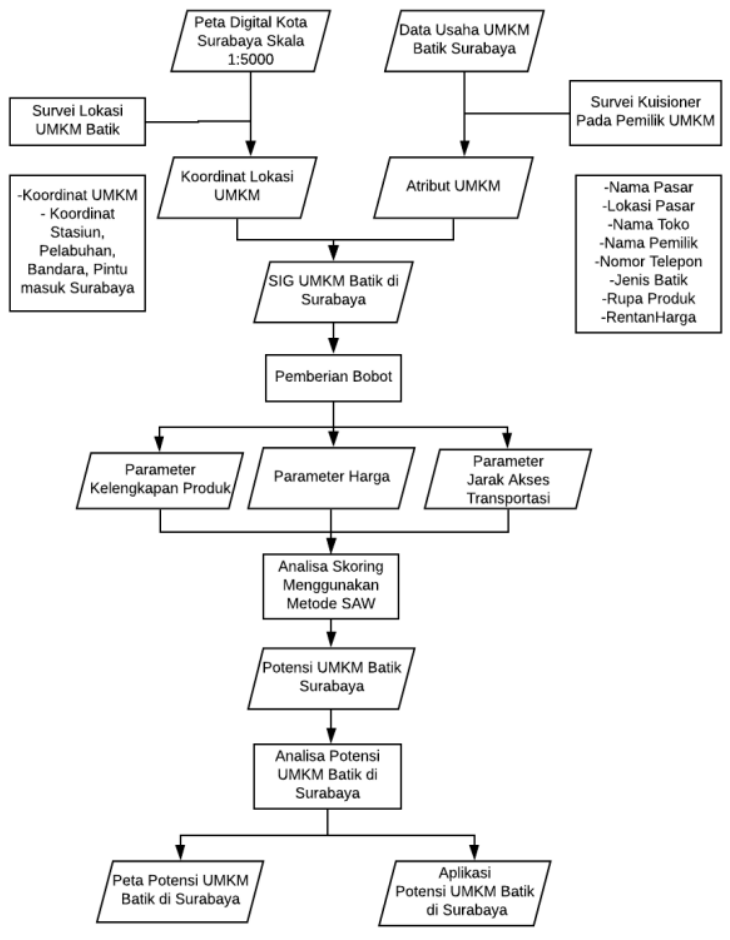

Figure 2. Flow Chart of Data Processing Stages.
Explanation of the data processing diagram above is:

1. Secondary data required is spatial data in the form of digital map of Surabaya city scale 1: 5000 and non spatial data in the form of business data of batik UMKM in Surabaya.

2. Survey Location of UMKM Batik At this stage conducted a field survey to obtain primary data in the form of coordinates of SMEs batik and verification of existing batik UMKM locations.

3. Survey of Questionnaires to MSME Owners This stage is done simultaneously during survey location of SMEs batik by using questionnaire addressed to owner of UMKM, questionnaire question related to attribute which will be used when compilation of SME Batik GIS.

4. Preparation of SMEs in SMEs Batik Surabaya Preparation of GIS SMEs batik is a merger and preparation of spatial data in the form of coordinates and non-spatial data in the form of attributes obtained into SMEs batik SIG that will be used to analyze the potential of SMEs batik.

5. Giving Weight

Giving weight is an activity that aims to determine the weight of each with potential parameters that affect for SMEs batik.

6. Scoring Analysis Using SAW Method

Analysis conducted to obtain information about batik SMEs that potentially become a place of recommendation of batik SMEs in Surabaya.

7. Potential Analysis of SMEs Batik Analysis of potential UMKM batik based on criteria of batik UMKM parameters in Surabaya.

8. Potential Map of SMEs Batik in Surabaya Map of potential batik SMEs in Surabaya can be obtained after obtaining the results of the potential analysis of batik SMEs in Surabaya.

9. Potential Application of SMEs Batik in Surabaya Potential applications of batik SMEs in Surabaya made using CarryMap to facilitate users in using batik SIG in Surabaya

\section{RESUlt AND ANALYSIS}

\section{A. Analysis}

1. Transport Access Criteria

Criteria of distance to access transportation aims to know UMKM Batik is close to access transportation. In this study the transportation access is referred to the stations, terminals, and ports in Surabaya. Assuming that a person walking has an average speed of $5-10 \mathrm{~km} / \mathrm{h}$ when traveling a distance of $2.5 \mathrm{~km}$ then it takes time for him to reach the location of MSME is 15-30 minutes. While people who ride the vehicle in the city has an average speed of $20-40 \mathrm{~km} / \mathrm{h}$ if the distance of $2.5 \mathrm{~km}$ then it takes time for up to the location of MSME is $4-7.5$ minutes. So a distance of $2.5 \mathrm{~km}$ is considered reasonable by the author to obtain the highest score with a score of 15 and the lowest score of more than 5 $\mathrm{km}$ with a score of 5 . 
The $3^{\text {rd }}$ Geomatics International Conference 2018 July $12^{\text {th }} 2018$, Institut Teknologi Sepuluh Nopember, Surabaya, Indonesia

TABLE 1.

TRANSPORT ACCESS DISTANCE PARAMETERS

\begin{tabular}{|c|c|c|}
\hline No & $\begin{array}{l}\text { Transportation Distance } \\
\text { Parameters Distance }\end{array}$ & Score \\
\hline 1 & $0-2.5 \mathrm{~km}$ & 15 \\
\hline 2 & $2.5-5 \mathrm{~km}$ & 10 \\
\hline 3 & $>5 \mathrm{~km}$ & 5 \\
\hline
\end{tabular}

Then the result of data processing above is as follows:

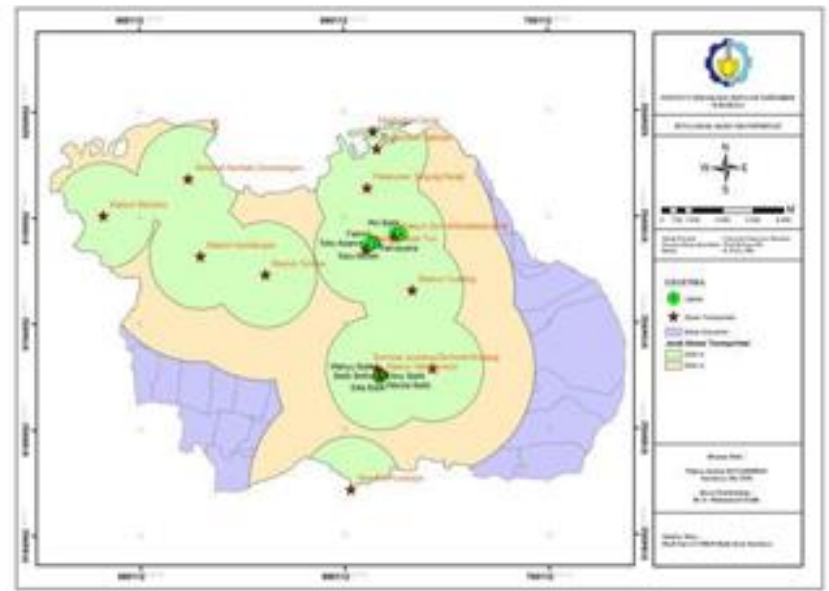

Figure 3. Map of MSMEs Distance on Transportation Access.

Based on the criteria of distance to access transportation, all batik SMEs have a high score with a score of 15 , because UMKM batik has a distance $<2.5 \mathrm{~km}$ from transportation entrance entrance of Surabaya, among others, stations.

TABLE 2.

Calculation of UMKM Batik BASEd on DisTANCE

\begin{tabular}{ccccc}
\hline \hline No & Distance & Score & $\begin{array}{c}\text { UMKM } \\
\text { Total }\end{array}$ & $\begin{array}{c}\text { Presentation } \\
(\%)\end{array}$ \\
\hline 1 & $0-2.5 \mathrm{~km}$ & 15 & 41 & 100 \\
2 & $2.5-5 \mathrm{~km}$ & 10 & 0 & 0 \\
3 & $>5 \mathrm{~km}$ & 5 & 0 & 0 \\
& Total & & 41 & 100 \\
\hline \hline
\end{tabular}

2. Price Criteria on Community Purchasing Power

Price criteria to public purchasing power aims to find out MSMEs that have economic prices that can be reached by people from middle to lower economic society up to middle and upper economic communities

TABLE 3.

PRICE PARAMETERS TO PUBLIC PURCHASING POWER

\begin{tabular}{clcc}
\hline \hline No & \multicolumn{1}{c}{ MSME Price Range } & Class & Score \\
\hline 1 & Rp. $30.000-100.000$ & ekonomis & 9 \\
2 & Rp. $100.000-200.000$ & menengah ke bawah & 7 \\
3 & Rp. $200.000-300.000$ & menengah & 5 \\
4 & Rp. $300.000-500.000$ & menengah ke atas & 3 \\
5 & Rp. $500.000<$ & atas & 1 \\
\hline \hline
\end{tabular}

Based on price criteria, batik SMEs have the highest presentation that is with a score of 7 a number of 26 SMEs, while those who have the lowest presentation with a score of 3 a number of UMKM.
TABLE 4.

CALCUlation OF UMKM BATIK BASED ON PRICE

\begin{tabular}{ccccc}
\hline \hline No & MSME Price Range & Score & $\begin{array}{c}\text { UMKM } \\
\text { Total }\end{array}$ & $\begin{array}{c}\text { Presentation } \\
(\%)\end{array}$ \\
\hline 1 & Rp. $30.000-100.000$ & 9 & 4 & 9.756098 \\
2 & Rp. $100.000-200.000$ & 7 & 26 & 63.41463 \\
3 & Rp. 200.000-300.000 & 5 & 7 & 17.07317 \\
4 & Rp. 300.000-500.000 & 3 & 1 & 2.439024 \\
5 & Rp. 500.000 & 1 & 3 & 7.317073 \\
& Jumlah & & 41 & 100 \\
\hline \hline
\end{tabular}

3. Product Type Criteria Against Product Completion

Product completeness criteria aim to know the UMKM which have complete product. Complete product in question is starting from accessories products, fabric, kid's clothes, and adult clothes. The more complete the product, the higher the score.

TABLE 5. TYPE PARAMETERS

\begin{tabular}{ccc}
\hline \hline No & Types of products & Score \\
\hline 1 & $\begin{array}{c}\text { Adults, Children's Clothes, } \\
\text { Fabrics / Accessories } \\
\text { Adults, Children's Clothes } \\
\text { Adult, Fabrics Materials } \\
\text { Adults, Accessories } \\
2\end{array}$ & 3 \\
3 & Adult & 2 \\
\hline \hline
\end{tabular}

Based on product criteria, batik SMEs have the highest presentation with a score of 1 a number of 22 SMEs, while those who have the lowest presentation with a score of 3 a number of 2 MSMEs

TABLE 6.

CALCULATION OF UMKM BATIK BY PRODUCT

\begin{tabular}{ccccc}
\hline \hline No & Product & Score & $\begin{array}{r}\text { Total } \\
\text { UMKM }\end{array}$ & $\begin{array}{c}\text { Presentation } \\
(\boldsymbol{\%})\end{array}$ \\
\hline \multirow{2}{*}{$\begin{array}{c}\text { Adults, } \\
1\end{array}$} & Children's & 3 & & \\
& Clothes, Fabrics & & 2 & 4.878049 \\
& / Accessories & & & 21.95122 \\
& Adults, Children's Clothes & & 9 & 17.07317 \\
& Adult, Fabrics Materials & 2 & 7 & 2.439024 \\
3 & Adults, Accessories & & 1 & 53.65854 \\
& Adult & 1 & 22 & 100 \\
\hline \hline
\end{tabular}

4. Potential Analysis of SMEs Batik

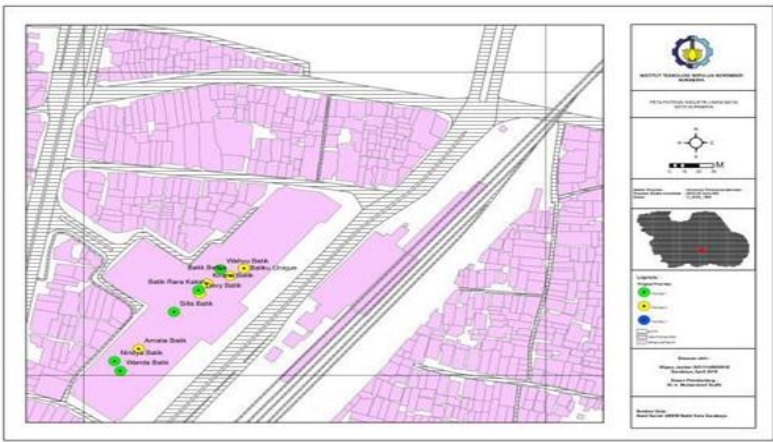

Figure 4. Position Map of MSME Priority in Pasar DTC. 
The $3^{\text {rd }}$ Geomatics International Conference 2018

July $12^{\text {th }} 2018$, Institut Teknologi Sepuluh Nopember, Surabaya, Indonesia

After doing the above three analysis of the analysis of distance criteria, price, and completeness of the product can be obtained MSMEs that have the highest score and lowest score. UMKM batik which has the highest total score that is with score 26 and has the lowest total score is with score 17. The author divides the potential of UMKM batik into 3 priority that is UMKM with high priority or priority 1 that is with score $24-26$, medium priority medium or priority 2 ie with a score of 20-23, and UMKM low priority or priority 3 is the score 17-19.

Position Map of MSME Priority in Pasar DTC (Fig. 4) MSMEs priority 1 is 5 MSMEs in South Surabaya in DTC market, 6 UMKM in Central Surabaya, 3 in Turi market and 3 in PGS market, and 2 UMKM in North Surabaya, 1 in Atom market and 1 in ITC market. Results of data processing can be seen in Table 7 .

TABLE 7.

LIST AND TOTAL SCORE UMKM BATIK PRIORITY

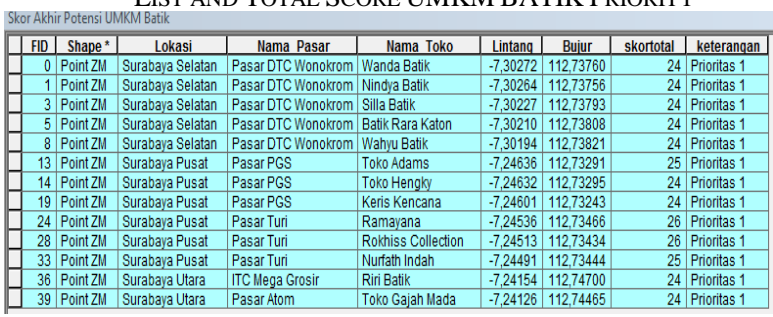

UMKM which is medium priority or priority 2 is 24 units. MSMEs in South Surabaya are divided into 2 markets in DTC, 17 MSMEs in Central Surabaya, 10 in Turi market and 7 in PGS market, and 2 MSMEs in North Surabaya are 1 in Atom market and 1 in ITC market. Results of data processing can be seen in Table 8 .

TABLE 8.

LIST AND TOTAL SCORE OF UMKM BATIK PRIORITAS 2

\begin{tabular}{|c|c|c|c|c|c|c|c|}
\hline FID & Shape $^{*}$ & Lokasi & Nama Pasar & Nama Toko & Lint & Buiur & \begin{tabular}{l|l|l} 
skortotal & keterano \\
\end{tabular} \\
\hline & $\frac{P \text { Point ZM }}{\text { Point }}$ & Surabaya Selatan & Pasar DTC Wonolirom & Amalia Bailik & $-7,30255$ & 112,73771 & \\
\hline & Point ZM & Surabaya Selatan & Pasar DTC Wonokrom & & & & \\
\hline & & Surabaya Selatan & Pasar DTC Wonokrom & Kirana Batk & & 12,73813 & 23 Prionitas 2 \\
\hline & Point ZM & Surabaya Selatan & Pasar DTC Wonokrom & BatikBetha & $-7,30199$ & 112,73827 & 22 Prionitas 2 \\
\hline & Point ZM & Surabaya Selatan & Pasar DTC Wonokrom & Baliks Unique & $-7,30194$ & 112,73836 & Prioitas 2 \\
\hline 10 & Point ZM & Surabaya Pusat & Pasar PGS & Aneka Batik & $-7,24652$ & 112,73262 & Prionitas 2 \\
\hline 11 & Point ZM & Surabaya Pusat & Pasar PGS & Sekar Jagad & $-7,24648$ & 112,73290 & 22 Prionitas 2 \\
\hline 12 & Point ZM & Surabaya Pusat & Pasar PGS & Ideal Batik & $-7,24645$ & 112,73312 & 23 Prionitas 2 \\
\hline & Point ZM & Surabaya Pusat & Pasar PGS & Toko Mabrur & $-7,24629$ & 112,73292 & 23 Prioititas 2 \\
\hline 16 & Point ZM & Surabaya Pusat & Pasar PGS & Fatiroh & & 112,73276 & 23 Priontas 2 \\
\hline & Point ZM & Surabaya Pusat & Pasar PGS & Toko Murah & & 112,73262 & Prioritas 2 \\
\hline 18 & Point ZM & Surabaya Pusat & Pasar PGS & Sutra Putih & $-7,2$ & 112. & Prionitas 2 \\
\hline & PointZM & Surabaya Pusat & Pasar Turi & Rafico & & 112. & 23 Prionitas 2 \\
\hline & Point ZM & Surabaya Pusat & Pasar Turi & Toko Aisyah Store & $-7,2$. & 112,73434 & 21 Prionitas ? \\
\hline & Point ZM & Surabaya Pusat & Pasar Turi & Sallys S & & 112,73449 & 23 Prionitas ? \\
\hline 25 & Point ZM & Surabaya Pusat & Pasar Turi & tun Kaira & & 112,73472 & Prionitas 2 \\
\hline 26 & Point ZM & Surabaya Pusat & Pasar T & VAWCol & & 112,73495 & 23 Prionitas 2 \\
\hline 27 & $\begin{array}{l}\text { Point ZM } \\
\text { Point }\end{array}$ & Surabaya Pusat & Pasar Turi & Aldo Coll & $-7,24$ & \begin{tabular}{|l|l|}
112,73477 \\
11172517
\end{tabular} & \\
\hline 29 & Point ZM & Surabaya Pusat & Pasar Turi & Toko Nurhamida & $-7,24512$ & 112,73517 & Prior \\
\hline 30 & Point ZM & Surabaya Pusat & Pasar Turi & Rizki House & $-7,24505$ & 112,73478 & 22 Prioritas 2 \\
\hline 31 & Point ZM & Surabaya Pusat & Pasar Turi & Cha Cha Collecion & $-7,24505$ & 112,73453 & 23 Prioritas 2 \\
\hline 32 & Point ZM & Surabaya Pusat & Pasar Turi & Ayezet Batik & $-7,24499$ & 112,73495 & Prionitas 2 \\
\hline$\frac{37}{38}$ & $\begin{array}{c}\text { Point ZM } \\
\text { PointzM. }\end{array}$ & $\begin{array}{l}\text { Surabaya Utara } \\
\text { Surbahara Utara }\end{array}$ & ITC Mega Grosir & Anisa Batik & $\begin{array}{r}-7,24131 \\
-724128 \\
\end{array}$ & 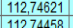 & $\frac{23 \text { Prioitas } 2}{23 \text { Pripitats }}$ \\
\hline
\end{tabular}

UMKM including low priority or priority 3 of 4 units. The spread of UMKM priority 3 is among others 1 SME in Central Surabaya that is in Turi market, 3 UMKM in North Surabaya that is in ITC market. The results of data processing can be seen in Table 9.

TABLE 9.

LIST AND TOTAL SCORE OF UMKM BATIK PRIORITY 3.

\begin{tabular}{|c|c|c|c|c|c|c|c|c|}
\hline FID & | Shape * & Lokasi & Nama Pasar & Nama Toko & Lintang & Bujur & skortotal & keterangan \\
\hline & Point ZM & Surabaya Pusat & Pasar Turi & Srikandi Shop & .724549 & 11273444 & & Prioritas 3 \\
\hline 34 & Point ZM & Surabaya Utara & ITC Mega Grosir & Batik Chrisna & $\begin{array}{r}-724180 \\
\end{array}$ & 11274713 & & Prioritas 3 \\
\hline 35 & PointZM & Surabaya Utara & ITC Mega Grosir & Toko Riezki 2 & $-7,24155$ & $\begin{array}{l}112,74717 \\
\end{array}$ & 17 & Prioritas 3 \\
\hline 40 & Point ZM & Surabaya Utara & ITC Mega Grosir & Njonjah Poenja & $-7,24119$ & 112,74623 & & Prioritas 3 \\
\hline
\end{tabular}

5. GIS Application Display Potential of UMKM Batik in Surabaya

SIG Potential of UMKM Batik in Surabaya has display menu identify. Identify on the map is given to assist users in understanding the information contained in the spread of batik SMEs. The results of this identifying information will appear next to the map.

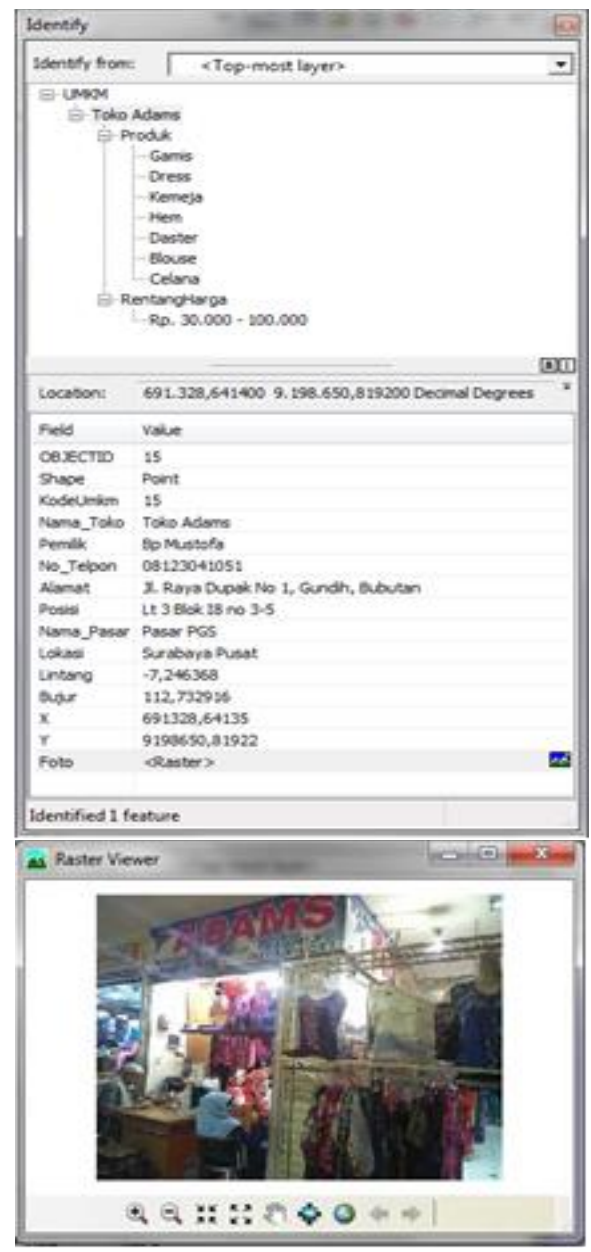

Figure 5. Display results identify.

In the application that is formed, there is a search function that in this case serves as an identify between attributes and spatial data. This search function is directly connected to the database.

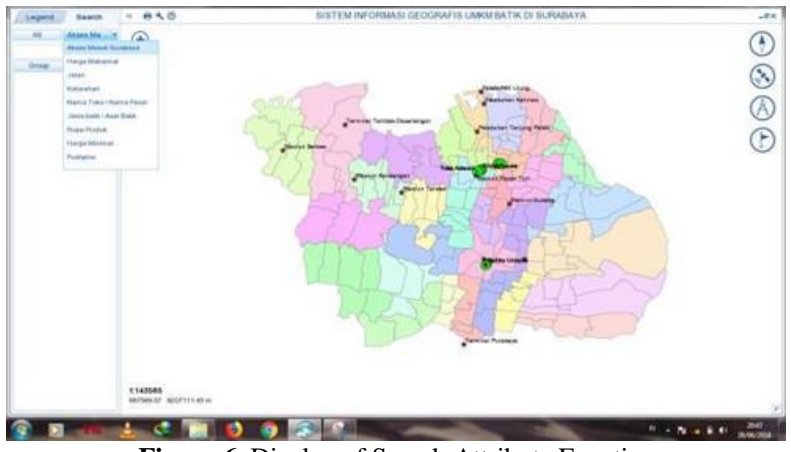

Figure 6. Display of Search Attribute Function. 
The $3^{\text {rd }}$ Geomatics International Conference 2018

July $12^{\text {th }} 2018$, Institut Teknologi Sepuluh Nopember, Surabaya, Indonesia

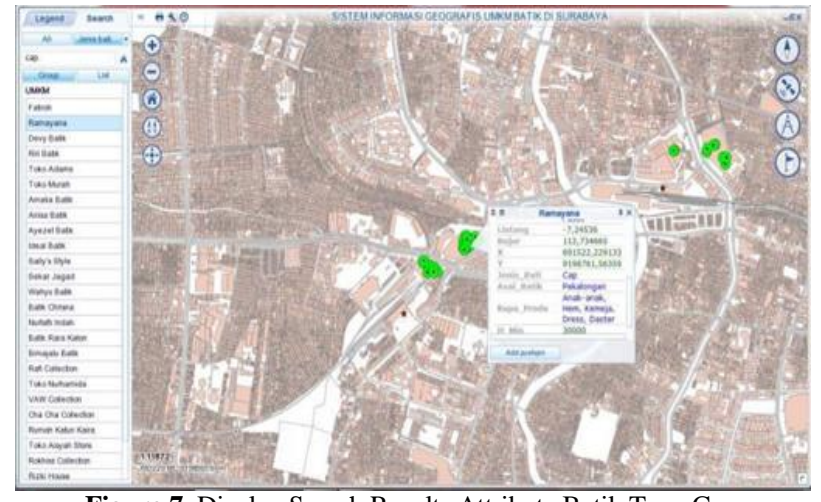

Figure 7. Display Search Results Attribute Batik Type Cap.

\section{Data Analysis}

Based on the database and the spread of 41 SMEs Surabaya batik that can be concluded that the SMEs of Surabaya batik priority 1 or high priority are many in South Surabaya, namely DTC market, priority 2 or priority are many in Central Surabaya namely Turi market, PGS market and Atum market, whereas priority 3 or low priority is mostly found in North Surabaya namely ITC Market.

TABLE 10.

NUMBER OF SMES BATIK IN SURABAYA

\begin{tabular}{|c|c|c|c|c|c|c|}
\hline No & Market & $\begin{array}{c}\text { MSME } \\
\text { Priorit } \\
\text { y High } \\
\text { Total }\end{array}$ & $\begin{array}{c}\text { MSMEs } \\
\text { Priority } \\
\text { Medium } \\
\text { Total }\end{array}$ & $\begin{array}{c}\text { MSMEs } \\
\text { Priority } \\
\text { Low } \\
\text { Total }\end{array}$ & Total & $\underset{n}{\text { Explanatio }}$ \\
\hline 1 & DTC & 5 & 5 & 0 & 10 & $\begin{array}{c}\text { High } \\
\text { Potency }\end{array}$ \\
\hline 2 & Turi & 3 & 10 & 1 & 14 & $\begin{array}{l}\text { Medium } \\
\text { Potency }\end{array}$ \\
\hline 3 & PGS & 3 & 7 & 0 & 10 & $\begin{array}{l}\text { Potency } \\
\text { Medium }\end{array}$ \\
\hline 4 & Atum & 1 & 1 & 0 & 2 & Potency \\
\hline 5 & ITC & 1 & 1 & 3 & 5 & $\begin{array}{c}\text { Low } \\
\text { Potency }\end{array}$ \\
\hline
\end{tabular}

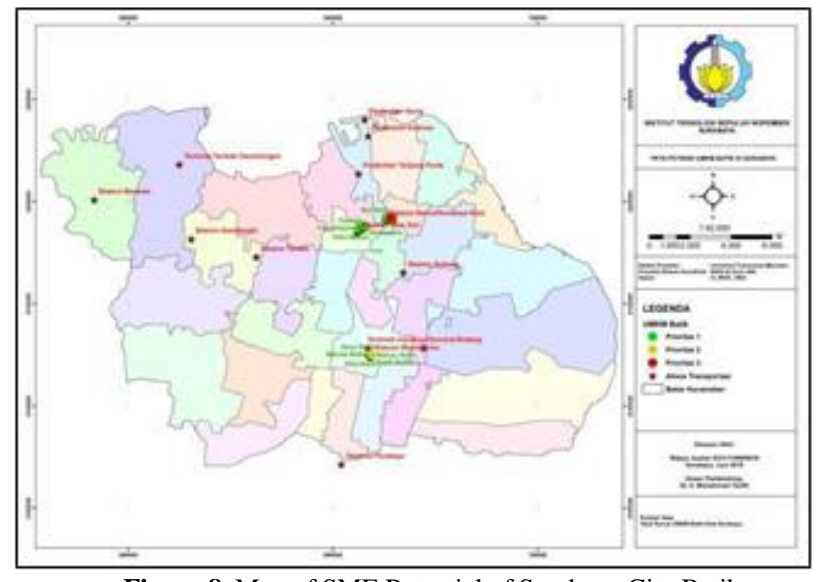

Figure 8. Map of SME Potential of Surabaya City Batik
Based on the results of research analysis has been put forward, it can be concluded as follows:

1. The potential of SMEs in Surabaya batik is divided into three priorities, among others:

a. High Priority or I, are batik SMEs that have a score of 24 - 26 a total of 13 SMEs with a presentation of $31.7073 \%$.

b. Medium or Second Priority, is batik MSME which has score 20 - 23 number 24 UMKM with presentation equal to $58.5365 \%$.

c. Low Priority or III, batik UMKM which have score 17 - 19 number 4 UMKM with presentation equal to $9.75609 \%$.

While the spread of UMKM batik in Surabaya, among others:

a. High Priority or I, among others, 5 MSMEs in South Surabaya are DTC market, 6 SMEs in Central Surabaya are 3 in Turi market and 3 in PGS market, 1 UMKM in North Surabaya is at Atom market, and 1 UMKM in East Surabaya in the ITC market.

b. Medium or Second Priority are 5 MSMEs in South Surabaya in DTC market, 17 UMKM in Central Surabaya are 10 in Turi market and 7 in PGS market, 1 UMKM in North Surabaya is at Atom market, and 1 UMKM in East Surabaya in the ITC market.

c. Low Priority or III, among others, 1 SME in Central Surabaya is in Turi market and 3 UMKM in East Surabaya is in ITC market

2. From the results of data collection from the questionnaire of batik SMEs in Surabaya, the results obtained in the form of Geographic Information System SMEs Surabaya Batik.

\section{ACKNOWLEDGMENT}

The author thanked Department of Cooperatives and Small, Micro and Medium Enterprises Surabaya that has helped in collecting data and information about batik MSMEs in Surabaya.

\section{REFERENCES}

[1] International Monetary Fund, "Real GDP Growth," 2017.

[2] A. Anggraeni, "Pembangunan Sistem Informasi Geografis Berbasis Web untuk Pemetaan Industri Kreatif Berbasis Budaya di Kota Surakarta,” Inst. Teknol. Sepuluh Nop., 2016.

[3] Pemerintahan Republik Indonesia, "Undang-Undang Republik Indonesia Nomor 20 Tahun 2008 Tentang Usaha Mikro, Kecil, dan Menengah," 2008.

[4] [BPS] Badan Pusat Statistika, "Perkembangan UMKM Periode 2016 - 2017,” 2017.

[5] A. Ayuningsasi and A. M. P. Paramita, "Efektivitas dan Dampak Program Revitalisasi Pasar Tradisional di Pasar Agung Peninjoan," Bali, 2013.

[6] S. Aronof, Geographic Information Systems: A Management Perspective. Canada: WDL Publications Ottawa, 1991.

[7] A. Musman and A. B. Arini, Batik Warisan Adiluhung Nusantara. Yogyakarta: G-Media, 2011. 